\title{
One Size Fits all or Tailor-Made? Building Appropriate Certification Systems for Geographical Indications in Southeast Asia
}

\author{
Delphine Marie-Vivien ${ }^{1}$ and Isabelle Vagneron ${ }^{2}$
}

\begin{abstract}
Geographical indications (GIs) - i.e. indications identifying goods originating in a specific place and having quality, characteristics, and reputation attributable to their geographical origin-are developing fast in the Southeast Asian food sector, with a wide range of new products such as Khao Hom Mali and Thung Kula Rong-Hai (fragrant rice), Kampot pepper, or Nuoc Mam Phu Quoc (fish sauce). After concentrating their efforts on registering GIs (to protect the name against counterfeit), GI promoters needed to decide how to control product compliance with GI specifications for specific quality. This paper analyzes the control and certification procedures for GIs in four Southeast Asian countries-Thailand, Vietnam, Cambodia, and Laos-and the challenges faced in building an efficient yet appropriate system of controls in these countries. Influenced by the "gold standard" of certification in place of organic agriculture, finding appropriate GI control systems is one of the dilemmas faced by these countries. The article discusses the main differences between GIs and other agricultural standards-specifications that are unique to each GI, endogenous, and based on local production practices-and the consequences in terms of certification. Indeed, in the case of GIs, other options than private third-party certification could better ensure that GI rules are followed, which may rely on the knowledge producers and connoisseurs have of the product.
\end{abstract}

Keywords: geographical indication, control, third-party certification, standard, ASEAN

1 1) CIRAD, UMR INNOVATION, F-34398 Montpellier, France, 2) INNOVATION, Univ Montpellier, CIRAD, Montpellier, France, 3) MALICA research platform, Hanoi, Vietnam

2 1) CIRAD, UMR INNOVATION, F-34398 Montpellier, 2) MOISA, Univ Montpellier, CIRAD, Montpellier, France 3) MALICA research platform, Vientiane, Lao PDR 


\section{RESUMEN}

Las indicaciones geográficas (GIs) - por ejemplo, indicaciones que identifican bienes que originan en algún lugar específico y que tienen una calidad, características y reputación que se le pueden atribuir a su origen geográfico-están teniendo un rápido desarrollo en el sector alimenticio del sudeste asiático, con un rango amplio de nuevos productos como Khao Hom Mali y Thung Kula RongHai (arroz aromático), Pimienta de Kampot o Nuoc Mam Phu Quoc (salsa de pescado). Después de concentrar sus esfuerzos en registrar GIs (para proteger el nombre contra las falsificaciones), los promotores de las GIs necesitan decidir cómo controlar el cumplimiento del producto con las especificaciones de las GIs para una calidad específica. Este documento analiza los procedimientos de control y certificación para las GIs en países del sudeste asiático-Tailandia, Vietnam, Camboya y Laos-y los desafíos que se enfrentan al crear sistemas de controles que sean eficientes y también apropiados en estos países. Bajo la influencia del "estándar dorado" de la certificación en lugar de la agricultura orgánica, encontrar sistemas de control de GIs apropiados es uno de los dilemas que enfrentan estos países. Este artículo discute las principales diferencias entre las GIs y otros estándares agrícolas-especificaciones que son únicas para cada GI, endógenas y basadas en prácticas de producción local-y las consecuencias en términos de la certificación. De hecho, en el caso de las GIs, opciones diferentes a la certificación privada de terceros podrían ser mejores para asegurarse que las reglas de las GI se sigan, lo que podría depender del conocimiento que los productores y expertos tienen del producto.

Palabras clave: indicación geográfica, control, certificación de terceros, estándar, ASEAN

\section{摘要}

地理标志 (Geographical indications, GIs) 一即能够识别商品 源自特定地点并具备可归因于该地理来源的品质、特性和声 誉的标志一正在东南亚粮食产业中迅速发展, 许多新产品由 此诞生, 例如Khao Hom Mali 和 Thung Kula Rong-Hai (泰国香 米), Kampot pepper（贡布胡椒）和Nuoc Mam Phu Quoc（越 
南鱼露）。GI推动者集中精力注册地理标志（用以保护产品 名称，抵制假冒）后，需要决定如何控制产品达到GI规范， 获得特定品质。本文分析了东南亚四国地理标志的控制和认 证程序, 这四国分别是泰国、越南、柬埔寨和老挝。同时分 析了以上国家在建立高效且适宜的控制系统时面临的挑战。 受到有机农业产地的 “黄金标准” 认证的影响，找到适合的 地理标志控制系统是这些国家面临的困境之一。本文探讨了 地理标志和其他农业标准间的主要差异, 后者对每一项地理 标志而言都是独特的、具有内源性、且基于地方生产实践。 文章还探讨了认证结果。的确, 针对地理标志, 比第三方认 证更能确保GI规定得以遵循的选择方式可能要依赖生产者和 内行对产品知识的把握。

关键词：地理标志，控制，第三方认证，标准，东盟

Acknowledgments: We gratefully acknowledge financial support from the French Development Agency (AFD) under its Project "Promotion of Rural Development through Development of Geographical Indications at Regional Level in Asia" implemented by FAO, which funded the "Study (diagnostics and recommendations) to assess national GI control/certification systems and identify GI certification options at national and regional levels". This study was carried out by D. Marie-Vivien, I. Vagneron, R. Cozzo, and D. BuiKim in 2015. Finally, we especially thank two anonymous referees for their extremely useful comments and suggestions.

\section{Introduction}

A geographical indication (GI) identifies a good as originating in a place, where a given quality, reputation, or any other characteristic of the good is essentially attributable to its geographical origin. GIs encourage diverse agricultural, food, and handicraft production and contribute to the socioeconomic dynamics of the regions in which they are anchored. They enable producers and operators to dedicate themselves to the commercialization of traditional products in response to the demands of quality-conscious consumers while promoting regional development (Bowen 2010). The aims of the legal protection conferred by the GI are to protect the producers against unfair competition and misappropriation, to protect consumers against a misleading description of the origin of the product, and to foster international trade 
(Crespi and Marette 2003; Rangnekar 2004; Barham and Sylvander 2011). Since the implementation of the WTO Agreement on Trade Related Aspects of Intellectual Property Rights (TRIPS Agreement 1994), GI protection has expanded remarkably worldwide (Evans and Blakeney 2006), in particular in Asia. Despite different economic contexts and different GI schemes, Cambodia (François and Prak 2006), Thailand (Ngokkuen and Grote 2013), Vietnam (Pick, Marie-Vivien, and BuiKim 2015), and Lao PDR (Marie-Vivien and Chabrol 2014), all have opportunities to develop high-quality products with a strong geographical identity, and have already engaged in the identification and registration of GIs as a tool to expand their presence on international markets.

Examples of emerging GIs in South-East Asia include: Khao Hom Mali and Thung Kula Rong-Hai fragrant rice (Thailand), Kampot Pepper (Cambodia), Nuoc Mam Phu Quoc (Vietnam), or Bolaven coffee (Laos). Despite encouraging developments, challenges to maximizing GI development in the region persist at institutional and operational levels. One of these challenges is to enhance capacity for GI control. A GI is a signal that a product possesses certain qualities and characteristics, and enjoys a certain reputation related to its geographical origin. Such information is described in the GI specification, and compliance with the GI specifications by the value chain operators must be properly controlled to maximize trust by local and international buyers/consumers. An independent efficient GI control system is consequently vital to allow the system to benefit all the parties involved. Failure in the control system is likely to significantly reduce the benefits of GI protection, and to damage the image of the GI product and its economic prospects, both locally and abroad. In addition to GI control requirements expressed in national laws and regulations (when these exist), exporting GI products to foreign markets may also require compliance with the requirements of the importing country (Bramley, Marie-Vivien, and Biénabe 2013). In the EU, while GIs are qualified as an Intellectual Property Right (IPR), their control system is increasingly similar to those developed for agri-food voluntary standards such as "Label Rouge" ("Red Label" superior quality standard) in France \{Marie-Vivien, 2017 \#609\} or organic agriculture, in which third-party certification prevails. For example, in France, GI control must be carried out by an ISO 17065 accredited certification body. We hypothesize that EU regulations influence domestic schemes for GI controls in countries willing to export their products to Europe, for example in Vietnam, Lao PDR, Cambodia, and Thailand.

Many authors have studied the importance of third-party certification for voluntary standards such as organic agriculture or fair trade, and explain it in terms of neoliberal governmentality (Gibbon and Memedovic 2005; Guthman 2007; Hatanaka, Bain, and Busch 2005). Third-party certification also appeals to techno-scientific values such as independence, objectivity, and transparency in an attempt to increase trust 
and legitimacy among customers and to limit liability. In contrast, the literature on the control of GIs is much more limited, with some works describing the evolution of the governance of controls in France $\{$ Marie-Vivien, 2017 \#609\}, the effect of the certification costs in Italy (Belletti et al. 2007), or the issue of State intervention in controls in African developing countries (Hughes 2009). Other works aim to compare the governance of GIs with that of other voluntary standards (e.g., ecofriendly labels) by analyzing how the standard is set (its content) rather than how it is controlled (Marie-Vivien et al. 2014).

Third-party certification is now clearly expressed as the preferred option by the EU regulation on GIs and is mandatory in France. It is, therefore, important to understand how the need for third-party certification is handled in countries with a burgeoning GI system, and how it builds on control mechanisms already in place for other voluntary standards.

The purpose of the paper is thus to analyze the options for GI control in four Asian countries-Thailand, Cambodia, Vietnam, and Laos-and to highlight the challenges faced by these countries, which have very different control capacities. We highlight the close relationship between the diffusion of the third-party certification model for GI certification in Asian countries and the shift in GI control in the EU (with a specific focus on France) from public bodies and collective producer organizations towards third-party certification. Based on desk research and qualitative interviews conducted in each country, this paper details for each of the four countries: the GI system, the control mechanisms implemented for GIs (when these exist), the control mechanisms implemented for voluntary/compulsory standards (when no GI control exists), and the control mechanisms in place for pilot GIs. Ultimately, the paper aims to provide policymakers with relevant information on how to build efficient but appropriate GI control schemes at the country and regional level.

The rest of the article is organized as follows: Section 2 describes the GI control system in the EU; in Section 3, an analytical grid is used to compare the GI control schemes in the four countries. Section 4 is dedicated to a discussion of the results of our survey.

\section{A GI Control Model Advocated by the EU}

\subsection{Towards third-party certification}

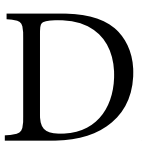
rawing largely on the tradition of appellation of origin, born in France in 1905 (Sylvander, Casabianca, and Roncin 2008), GIs have been homogeneously protected in the EU since 1992 by Regulation 2081/92 on the Protection of Geographical Indications (PGI) and Designations of Origin (PDO) for Agricultural Products and Foodstuffs. This is a two-tier system: the PDO/PGI application is first processed by the competent authority of the Member State in which the geographical area is located-e.g., the National Insti- 
tute for Origin and Quality (INAO) in France ${ }^{3}$ - the application is then examined by the Directorate General for Agriculture of the EU Commission.

In 2006, the EU Regulation was amended $^{4}$ to enable foreign GIs to benefit from protection within the EU and to introduce third-party certification, as defined in the EU food law. The regulation was again amended in 2012, to merge all quality certifications for food. The general EU food law principles reshaped the organization of controls by differentiating between what fell within the ambit of public authorities, and what could be delegated to private bodies.

Since EU regulation 510/2006 was promulgated, the overall control of the whole PDO/PGI system has to be ensured by the competent authority of the Member State. Monitoring compliance with the specification of each $\mathrm{PDO} /$ PGI can be ensured by the competent authority of the Member State and/or by a certification body, i.e. an independent body in charge of inspecting and certifying the conformity of the PDO/ PGI product with its specification, and accredited against the European standard EN 45011 or ISO/IEC 17065 . The certification body is accredited at the level of the Member State by the national accreditation body, which is the body responsible for officially recognizing the capability of the certification bodies to inspect and certify PDO/PGI specifications. The term "certification body", in- troduced by the 2006 regulation, marks the inclusion of PDO/PGI in the general standards for product certification (Gonzales Vaque 2006). Member States that choose a public entity to verify compliance with the specifications must offer adequate guarantees of objectivity and impartiality.

\subsection{The French case}

lthough it was not mandato-
ry, France chose to shift from
controls undertaken by the competent public authority (INAO) to controls undertaken by ISO 17 065-accredited certification bodies $\{\mathrm{Ma}$ rie-Vivien, $2017 \# 609\}$ accredited by the national accreditation body, COFRAC (French Accreditation Committee) and approved by INAO, which remains the supervisor of the control system. Before 2006, while controls were officially under the authority of INAO (public third-party control), in practice they were delegated by INAO to GI producer associations and were consequently considered as insufficiently impartial, especially concerning wines for which "arrangements" between producers were notorious (Olszak 2007). The objectives of shifting to third-party private certification bodies were to meet the expectations of consumers, who often questioned the impartiality and the effectiveness of controls, and to reduce public spending.

3 Even though INAO is governed by a Board composed of both public and private stakeholders (see Marie-Vivien et al. (2017)), INAO is recognized as the national competent authority in conformity with the EU Regulation.

4 Regulation (EC) No. 510/2006 of March 20, 2006 on the protection of geographical indications and designations of origin for agricultural products and foodstuffs. 
Figure 1: French system of GI control

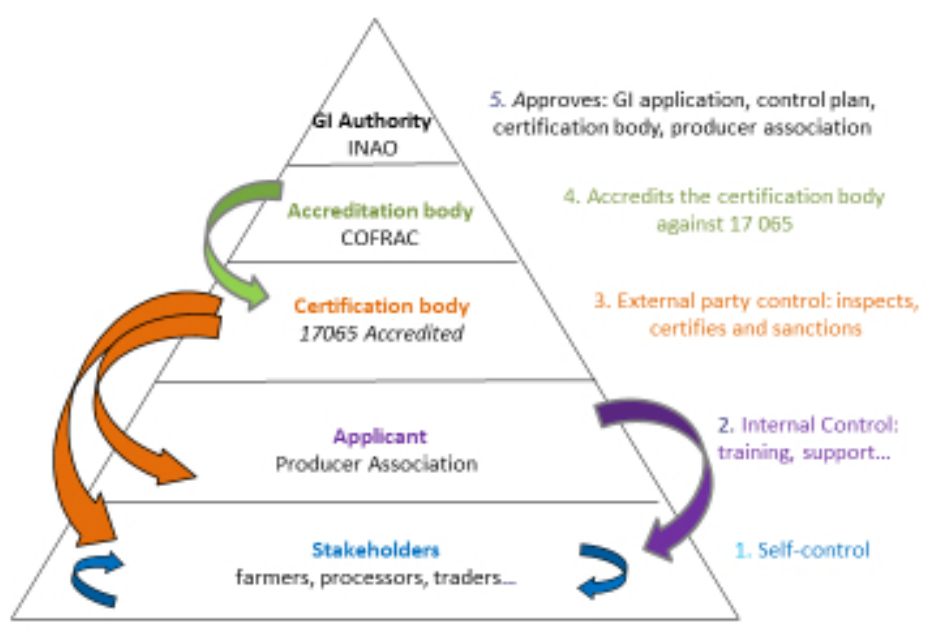

Source: Authors' survey, using initial figure of Certipaq.

Since 2006, in collaboration with the appropriate GI producer/processor organization (GI organization), for each PDO/PGI, the certification body has been designing a control plan based on the GI specification drafted by the GI organization. The certification body carries out the inspections and, based on the inspection reports, decides whether or not to grant certification. All costs incurred in monitoring compliance with the specification are borne by producers/processors. The sensory tests-which mainly involve tasting and were maintained for PDOs despite being criticized as subjective-are carried out by a panel of skilled producers and experts who can ensure that the inspection of the product is independent and impartial. The producer organizations are responsible for training their members and forming these panels, which still play an important role in charac- terizing the typicity/distinctiveness of PDOs and in recognizing the knowhow of the producers. In addition to external controls by the certification body, the control plan includes self-controls by producers/processors, and internal controls by the producer organization (audited by the certification body). Control by third-party certification bodies ends INAO's responsibility and the practice of delegating the organization of controls to GI organizations. In this process, the philosophy of control shifts from peer review to third-party control. ${ }^{5}$

\subsection{From gray zones to windows of opportunity}

I $t$ is the French/EU control and certification model that is now disseminated to countries implementing GI protection schemes. Indeed, EU Reg-

5 A similar shift was described for organic agriculture by Sylvander (1997) and by Muttersbaugh (2005). 
ulation 510/2006 clearly requires that, in the case of foreign GIs, verification of compliance with GI specifications is to be ensured by one or more public authorities designated by the third country and/or one or more product certification bodies, which, from May 1, 2010 onwards, shall be EU standard EN 45011 or ISO/IEC Guide 65 (now 17 065) ${ }^{6}$-accredited. Interestingly, when the EU Regulation on PDO/PGI was amended in $2012^{7}$ for GIs from third countries, the reference to the $\mathrm{EN}$ 45011 accreditation was dropped. In this context, third countries are left with a range of options: in October 2012, the Vietnamese GI Nuoc Mam Phu Quoc was registered in the EU as a PGI with a control system based on a Control Board $^{8}$ headed by a representative of the Agro-Forestry-Fisheries Division of Phu Quoc district; in 2013, Thai GI Khao Hom Mali Thung Kula Rong-Hai rice was also registered in the $\mathrm{EU}$ as a PGI, but was certified by Bioagricert, a European ISO 17 065-accredited certification body. Despite this apparent flexibility, control by a private accred- ited third-party certification body is strongly advocated and largely influences the architecture of GI control systems in many countries, in particular, in the four countries in our study.

\section{Appropriate for the Control of GIs in Southeast Asia?}

\subsection{National architectures for the protection of GIs}

eographical Indications have
been protected by suigeneris law
in Thailand since $2003,{ }^{9}$ in Vietnam since $2005,{ }^{10}$ in Cambodia since $2014^{11}$, and in the Lao PDR since 2011. ${ }^{12}$ Thailand is the region's GI champion, with 90 registered GIs-among which are 76 Thai GIs and 14 international GIs. Vietnam is also quite dynamic with 52 GIs for Vietnamese products and 6 GIs for foreign products. Finally, two GIs are currently registered in Cambodia for Cambodian products-Kampot pepper and Kompeug Speu palm sugar and two for foreign products. The Lao PDR has none yet, but has two possible

$6 \quad$ Art 11.2 of EU Regulation of 2006.

7 Regulation (EU) No. 1151/2012 of November 21, 2012 on quality schemes for agricultural products and foodstuffs.

8 October 19, 2005 decision by the People's Committee of Kien Giang Province approving the Regulation on the organization and operation of the Control Board for the Appellation of the Origin Controlled of Phu Quoc fish sauce.

9 Geographical Indication Protection Act, B.E. 2546 (2003).

10 Geographical indications were first protected by recognition of the appellation of origin introduced in the Civil Code of 1995, and later by the Intellectual Property Law drafted for the country's accession to the WTO.

11 Royal Kram No. NS/RKM/0114/006 dated January 20, 2014 promulgating the Law on Geographical Indications and its Ministerial Regulation (Prakas) on the Procedure for the Registration and Protection of Geographical Indications of December 29, 2016, replacing Prakas no. 105 MOC/ SM 2009 of May 18, 2009.

12 Law on Intellectual Property (No 08/NA, December 24, 2007) revised and amended by the National Assembly in 2011 (No. 01/NA, December 20, 2011), Regulation for the implementation of the law of October 25, 2016. 
GIs for Bolaven coffee and Khao Khai Noi rice and one application from a foreign country (Champagne).

In Thailand and Cambodia, the competent authority in charge of registering GIs is the Department of Intellectual Property (DIP) under the authority of the Ministry of Commerce, whereas in Vietnam and Laos, the competent authorities are under the authority of the Ministry of Science and Technology (the National Office of Intellectual Property in Vietnam and the Department of Intellectual Property in the Lao PDR).

The competent authorities are in charge of examining the GI applications, which will be the "standard" to be controlled, like in the EU. In contrast to the EU system, in which the nature of the applicant, a producer/processor group is always the same, the rules for a GI applicant are quite diverse in the four Asian countries. In Thailand, the GI applicant can either be a private entity (an individual person or a company), a group of producers/processors (association, cooperative, or non-formalized group), a group of consumers, or a public authority ${ }^{13}$ (Provincial Authorities, the Rice Department, the Queen Sirikit Department of Sericulture). ${ }^{14}$ In Vietnam, the right to register a GI belongs to the State, but the State can delegate it to organizations and individuals who produce the product bearing the GI, collective organizations, or the administrative authorities of the locality to which the GI pertains. ${ }^{15}$ In practice, applications are often filed by the provincial Department of Science and Technology, the Peoples' Committees of the province/district, or the Department of Agriculture and Rural Development of the province/district. In Cambodia and in the Lao PDR, the producer association is the only body authorized to apply for a GI. ${ }^{16}$

In contrast to other standards, what matters for the GI is the protection of a name (usually the geographical name of the location where it is produced). National GI logos indicating that the name is registered as a GI are increasingly used, especially since the GI concept is new in Asia. Thailand has its own GI logo, ${ }^{17}$ which reads "Thai Geographical Indication" and "GI” in Thai and in English characters against a gold background. In Cambodia, the national logo for GIs was launched in 2015 and in Lao PDR in 2016. Vietnam is in the process of launching its own logo.

The four countries have been following distinct pathways in implementing controls and certification systems: while Thailand's implementation of controls was quite gradual, Cambodia immediately jumped on the certifi-

13 Public authorities are sometimes involved in the preparation of the GI Book of Specifications, in cooperation with the local communities and with the DIP GI Office.

14 Section 7 of the GI Law 2003.

15 Art. of the IP Law 2005.

16 Art.2.5 of the Lao Decision 2016 on Geographical Indications and art.7 of the GI Law of Cambodia.

17 The use of the GI National Logo is regulated by the "Department of Intellectual Property's Regulation for Thai Geographical Indication Logo Approval B.E. 2008”. 
cation bandwagon with strong support from France, but applied it to only two GIs. At the other end of the spectrum, control systems for GIs are still far from operational in Vietnam and the Lao PDR, although certifications systems have been introduced for other standards and new avenues for certification are being explored (e.g. Participatory Guarantee Systems), which could be a source of inspiration.

\subsection{National accreditation systems}

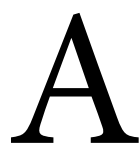
ccreditation bodies in charge of recognizing certification bodies' capability to certify standards exist in Thailand and Vietnam, both members of the International Accreditation Forum (IAF). While in Vietnam, the accreditation to certify the "GI standard" does not yet exist, Thailand already has a specific accreditation system for GIs. In Cambodia, institutions have been created but the accreditation scheme for product certification bodies is not yet in force. In the Lao PDR, the national accreditation system is under development as several initiatives are currently underway to connect emerging institutions with the global arena (no specific action has yet been taken for GI certification).

Accreditation of certification bodies in Thailand comes under the National Standardization Act B.E. 2551 (2008) and belongs to one network, the
National Accreditation Council, under the Ministry of Industry. ${ }^{18}$ The network includes several accreditation agencies including the National Bureau of Agricultural Commodity and Food Standards (ACFS), which is in charge of accrediting certification bodies for agricultural commodities and food products. ${ }^{19}$ In 2012, the DIP signed a Memorandum of Understanding with ACFS and the Thai Industrial Standards Institute on Cooperation for Certification and Recognition of Geographical Indications. The ACFS must now submit to the IAF an official request to include GIs as a standard to be certified besides other standards such as GAP (good agricultural practices) that are already recognized by IAF. Once this procedure is completed, the ACFS GI accreditation scheme will be internationally recognized as ISO 17 065-accredited by all members of the IAF. ${ }^{20}$ In the meantime, the ACFS can accredit certification bodies using Thai standards for GI certification.

In Vietnam, the accreditation body is the Bureau of Accreditation (BoA) established in 1995 under STAMEQ, the Directorate for Standards, Metrology and Quality of the Ministry of Science and Technology. ${ }^{21}$ The BoA offers accreditation programs for laboratories, certification bodies, and inspection bodies, for the certification of compulsory and voluntary standards, be they domestic, foreign, regional, or

18 https://www.tisi.go.th/home/en.

19 http://www.acfs.go.th/eng/.

20 Certification bodies that are already accredited by ACFS to certify standards such as GAP, GMP, and HACCP will be able to certify GIs.

21 http://www.boa.gov.vn/en. 
international. Voluntary standards in agro-food products include VietGap (Vietnam Good Agricultural Practices), safe vegetables, and organic agriculture. The BoA's accreditation programs operate according to international standards. The Vietnam Certification Accreditation Scheme (VICAS) is one of these programs. At the time of writing, certification bodies are only accredited to certify VIETGAP (not GIs).

The Cambodian Ministry of Industry and Handicraft has set up an Institute of Standards. A new product certification scheme conforming to the requirements of the ISO/IEC Guide 65 is currently being developed. The Department of Accreditation, created in 2016, is the authority responsible for Accreditation of Conformity Assessment Bodies, but Cambodia does not yet have an accredited body for GI certification. $^{22}$

The Lao PDR is currently setting up the Lao National Accreditation Bureau (LNAB) to be hosted by the Ministry of Science and Technology (Department of Standardization and Metrology) with the support of ASEAN's Consultative Committee on Standards and Quality (ACCSQ), which organizes training courses to strengthen accreditation services in Cambodia, Lao PDR, Myanmar, and Vietnam. The LNAB will be in charge of granting, maintaining, extending, suspending, and withdrawing accreditation to laboratories and conformity assessment bodies, among which are certification bodies. ${ }^{23}$ Once the LNAB is fully operational, certification bodies will be able to be accredited locally and will no longer have to rely on foreign accreditation services.

\subsection{Certification and control schemes for Geographical Indications}

T $\mathrm{n}$ Thailand, the law does not require a control mechanism for the use of the GI, i.e. the use of the name protected as a GI. This is different for producers/processors willing to use the Thai national GI logo. The producers/ processors group must file an application with the DIP and develop a GI operating manual and a control plan. ${ }^{24}$ In practice, the control plan is generally prepared with the support of the public authorities and is first implemented by the group of producers/processors (internal control) followed by external control by a Provincial Committee composed of individuals from the DIP, the local authorities, and producers/ processors. The external control can be delegated by the Provincial Committee to the Province or to another public agency. ${ }^{25}$ If there is no producer/processor group, the Provincial Committee

22 http://www.da-canc.gov.kh/en and http://www.isc.gov.kh/en/.

23 Decree on the Implementation of the Law on Standardization (June 2012).

24 ACT 2534 revised by ACT (No.5) BE 2545 (Art.1 point 5.1)

25 In 2015, 15 GIs used the Thai National GIs Logo; 39 GIs had the GIs Manual; 35 GIs had an Internal Control Plan; and 27 GIs also had a Committee to coordinate the control activity, take decisions, and verify the internal control. Of these 27, 19 had a "Provincial Committee". However, this system is not recognized internationally. 


\section{Figure 2: GI control system in Thailand}

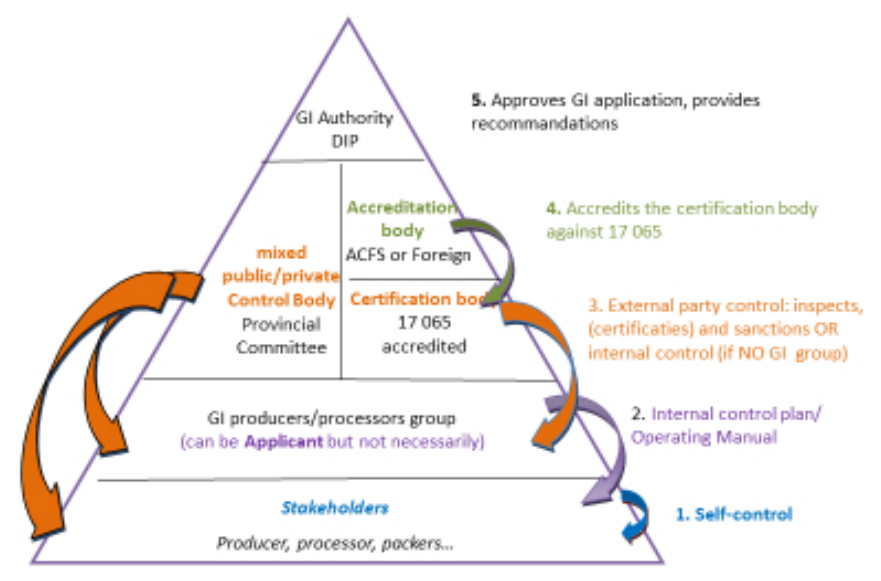

Source: Authors' survey.

can directly control all producers/processors.

The new 2012 regulation allows ISO $17 \quad 065$-accredited certification bodies to inspect and issue certificates for Thai GIs. This is a voluntary choice of the GI producer/processor groups. Such a certification body can be accredited by the EU or by the Thai ACFS once the new GI accreditation scheme is effective. The Thai system thus allows GI producers/processors to choose between several control options.

In Vietnam, in the absence of a homogeneous national system, rules for managing GIs, i.e. granting and revoking the right to use the GI, are very diverse. The right to use the GI is granted by the management body (the public authority that registered the GI), but is not conditional upon control of compliance of the product to the GI specification, even if in some cases control boards were created. The control board usually comprises representatives from the Directorate for Standards, Metrol- ogy and Quality (STAMEQ) under the MoST, at the Provincial level. Initially involved in the creation of the GI for Nuoc Mam Phu Quoc (fish sauce), NAFIQAD (National Agro-Forestry-Fisheries Quality Assurance Department, under the Ministry of Agriculture) mainly controls compliance with mandatory food safety regulations and with some voluntary standards such as VietGAP through a network of laboratories scattered around the country. It considers that State agencies should not be involved in the control of voluntary standards such as GIs. NAFIQAD is funded by the State and by certification fees. Hai Phong Branch employs 15 people for laboratory analyses, 15 people for certification, and 10 people for administrative work. Each department of the Ministry of Agriculture and Rural Development (MARD) is in charge of accrediting certification agencies against specific standards, which creates considerable confusion: e.g., the Department of Crop Production is in 
Figure 3: GI control system in Vietnam

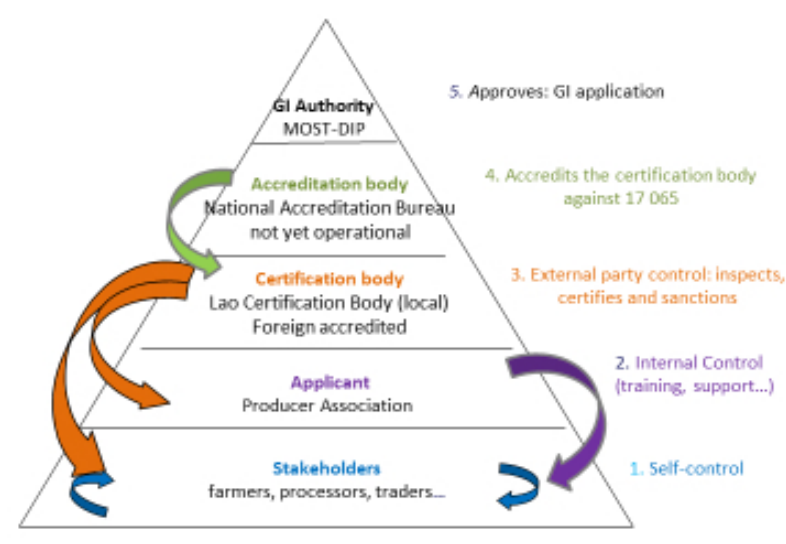

Source: Authors' survey.

charge of accrediting agencies for $\mathrm{Vi}$ etGap for crops, while the Department of Livestock is in charge of accrediting agencies for VietGap for livestock.

No certification bodies inspect GIs, although there are many private Vietnamese certification bodies accredited by foreign accreditation organizations, such as Vinacert, which certifies mangoes from Hoa Loc, tea from Van Chan, and tea from Yen Bai against VietGAP. In the absence of Vietnamese organic agriculture standards, foreign certification bodies-e.g., Organic Agriculture Thailand (ACT) in Thailandcertify that Vietnamese products comply with foreign organic agriculture standards. This is the case of organic tea from Yen Bai, or organic star anise from Lang Son, two GI products.

The GI control system developed by Cambodia is very similar to the French system. It is detailed and includes an internal control by the GI association, and is funded by a fee paid by all members (producers, processors, packagers) of the GI association, an external control by a private or public ISO 17 065-accredited certification body, chosen by the GI association and approved by the Ministry of Commerce, the authority responsible for official controls. $^{26}$ The certification body audits the internal control system and inspects a subsample of GI association members. As Cambodia does not yet have an accreditation system for GI or Cambodian certification bodies that would be internationally recognized, the two Cambodian GIs are controlled and certified by foreign certification bodies accredited in the EU. Indeed, the only certification body in the country is the Cambodian Organic Agriculture Association (COrAA), a small private organization in the sector promoting organic agriculture in Cambodia that is not recognized internationally but conducts a few inspections each year for foreign certification bodies willing to certify foreign standards (e.g., GAP,

26 Art.26 and 27 of the GI Law 2014 and art.37 to 41 of the Prakas of 2016. 


\section{Figure 4: GI control system in Cambodia}

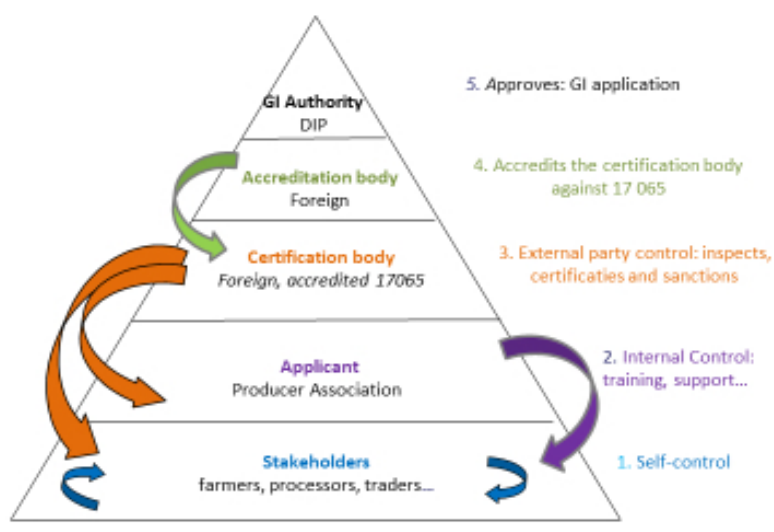

Source: Authors'survey.

organic). No laboratories are accredited to carry out analytical tests.

The Kampot pepper GI is a perfect illustration of how a multi-tiered system can work. It combines: (i) self-control at the producer/processor level (each producer/processor verifies the requirements of the specification using the "auto check list"); (ii) inspection of all the members of the GI association by the 18 inspectors working for the association's internal control system; (iii) inspection of $30 \%$ of the producer/processor and of the internal control system by Ecocert, the certification body. In 2014, 20\% of the pepper producers and $100 \%$ of the companies were reinspected by the external body. The organoleptic characteristics of the Kampot Pepper GI were verified by a sensory analysis panel. These checks showed that $95 \%$ of the producers kept their records properly, and that only a few needed to improve their record-keeping. Both the internal and the external control systems were satisfactory. Certification costs were borne by the GI association, owing to successful domestic and international sales of Kampot pepper.

The GI certification system in the Lao PDR is patterned after the French system. The DIP is the competent authority for official controls. Control of compliance with the GI specifications must be carried out by a certification/ control body that is (1) legally registered or authorized to provide control or certification activities in Lao PDR and (2) 17 065-accredited. The certification/control body has to send an annual report to the DIP including a list of certified producers, operators, products, quantities, and measures taken, if any. This system has not yet been implemented.

Since 2008, the national institution Lao Certification is in charge of providing certification services to the agriculture and food sectors. Currently it inspects and certifies that producers and producer groups comply with Lao national organic standards and national 


\section{Figure 5: GI control system of the Lao PDR}

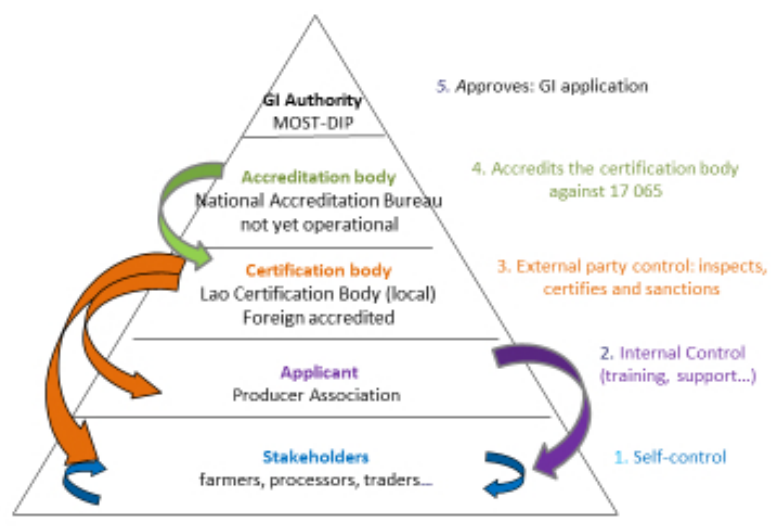

Source: Authors'survey.

standards for Good Agricultural Practices issued by the Ministry of Agriculture. The LCB is under the auspices of the Standard and Accreditation Division of the Department of Agriculture within the Ministry of Agriculture. It currently employs 12 permanent staff. The inspectors at LCB were trained by inspectors from the Department of Agriculture, Agriculture Certification Thailand (ACT), and the Thai Organic Trader Association (TOTA). Around 20 organic inspections of organic farms are currently conducted throughout the country each year. As there are no inspectors at the provincial and district levels, the inspectors cannot monitor the producer groups under their responsibility very closely. Operational ICSs have been developed for organic rice and vegetables (Vientiane Capital), the future GI Bolaven coffee (Champassak Province), and the future GI Khao Khai Noi (Xiengkhouang and Huaphanh provinces). Farmers are usually inspected once a year. The inspection process lasts between $2 / 3$ days and a week, depending on the number of farmers to be inspected in a group. Inspection of paperwork is usually followed by field inspections. Total certification costs depend on the size of the area to be inspected and certified and on the number of farmers involved, and may vary from 100,000 to $1,000,000$ LAK (US\$13-125). Organic Agriculture Certification Thailand (ACT) is the main certification body that performs inspections and certifies that products comply with foreign organic standards. For products for export, ACT currently invites LCB inspectors to take part in the inspection process to gain experience. However, the final certification process is carried out by ACT alone. Other foreign certification bodies operating in the Lao PDR include: BCS (Germany), ICEA (Italy), and Bioagricert (Italy), all of which operate from Thailand.

Table 1 summarizes and compares the GI systems in the four countries, underlining the difference between the approaches. 
Table 1: Comparison between the GI systems in Southeast Asia

\begin{tabular}{|c|c|c|c|c|}
\hline & Thailand & Vietnam & Cambodia & Lao PDR \\
\hline $\begin{array}{l}\text { Year of IP } \\
\text { Law }\end{array}$ & 2003 & 2005 & 2009 & 2011 \\
\hline $\begin{array}{l}\text { Competent } \\
\text { authority }\end{array}$ & $\begin{array}{l}\mathrm{MoC} \\
\mathrm{DIP}\end{array}$ & $\begin{array}{l}\text { MoST } \\
\text { NOIP }\end{array}$ & $\begin{array}{c}\mathrm{MoC} \\
\mathrm{DIP}\end{array}$ & $\begin{array}{l}\text { MoST } \\
\text { DIP }\end{array}$ \\
\hline GI applicant & $\begin{array}{l}\text { Private entity, } \\
\text { group of } \\
\text { producers, } \\
\text { public } \\
\text { authorities }\end{array}$ & $\begin{array}{c}\text { Local public } \\
\text { authorities } \\
\text { (can delegate to } \\
\text { the producers, } \\
\text { collective } \\
\text { organizations) }\end{array}$ & Association & Association \\
\hline $\begin{array}{l}\text { External } \\
\text { control }\end{array}$ & $\begin{array}{l}\text { Certification } \\
\text { bodies } \\
\text { or public } \\
\text { authorities- } \\
\text { operational }\end{array}$ & $\begin{array}{c}\text { Public } \\
\text { authorities } \\
\text { (Little } \\
\text { operational) }\end{array}$ & $\begin{array}{l}\text { Certification } \\
\text { bodies } \\
\text { (operational) }\end{array}$ & $\begin{array}{c}\text { Certification } \\
\text { bodies (not } \\
\text { operational) }\end{array}$ \\
\hline $\begin{array}{l}\text { Accreditation } \\
\text { body }\end{array}$ & $\begin{array}{c}\text { National } \\
\text { Standardization } \\
\text { Council } \\
\text { (member of } \\
\text { IAF) }\end{array}$ & $\begin{array}{c}\text { Bureau of } \\
\text { Accreditation } \\
\text { (member of } \\
\text { IAF) }\end{array}$ & $\begin{array}{c}\text { Department of } \\
\text { Accreditation } \\
\text { (not a member } \\
\text { of IAF) }\end{array}$ & $\begin{array}{c}\text { National } \\
\text { Accreditation } \\
\text { Board (not } \\
\text { operational, } \\
\text { not a member } \\
\text { of IAF) }\end{array}$ \\
\hline $\begin{array}{l}\text { GI national } \\
\text { logo }\end{array}$ & & In process & & \\
\hline $\begin{array}{l}\mathrm{N}^{\circ} \text { of } \\
\text { registered GIs }\end{array}$ & $76+14$ & $52+6$ & $2+2$ & - \\
\hline
\end{tabular}

Source: Authors' survey.

\section{Discussion}

\subsection{Choosing the "right" certification model}

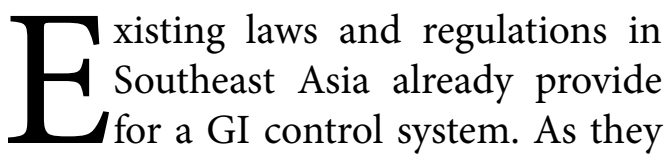

are not yet fully operational, we consider that several options are still open for drafting a credible certification system that is not prohibitively costly for the producers and remains manageable by local institutions. As certification is costly, to be sustainable it must be off- 
set by higher prices, which is seldom the case for new products that may not yet enjoy a reputation of uniqueness and quality beyond the borders of the producer country. Financing internal and external controls through member fees like in Europe does not seem appropriate for a burgeoning GI system that is not well remunerated because it not very well known by consumers. The EU model was successful for Kampot pepper, which benefits from a high premium on the international market, but its costs may be the reason why so few GIs have been registered in Cambodia since then.

Moreover, certification requires an entirely different attitude by the farmers, as they not only need to do things differently, but must also be able to prove that they actually do so. Experience in the four countries shows that it is often difficult for farmers and local communities to cope with the detailed technical requirements and to understand the need to "write what they do and do what they write" on a regular basis, as is often requested. This is likely to be the case for GI products that need to be traced from the farm to the fork. It may also be difficult for farmers to understand and follow the application process without external support (e.g., from an NGO) and in the absence of properly trained extension officers. The Lao Certification Body is severely understaffed and has no representatives at the district level to regularly train the farmers on certification procedures and paperwork, and on the importance of documenting farming practices.
Verification and certification systems are likely to be shaped by the distance to the final market on which the GI product will be sold, their cost, and by the financial and human assets available at both the farmer's and institutional level.

In the end, three main options exist for GI control:

(1) Control by 17 065-accredited certification bodies seems to be the best guarantee for access to distant markets. It guarantees that all members of the GI group apply the GI specifications in the same way. This is an important step to avoid the misuse of the GI name and logo. This certification system makes it more difficult for fraudulent operators outside the group to produce GI product counterfeits as these operators will not have the GI certificate to prove the authenticity of their products. Such a system could be implemented either by foreign certification bodies or, better by far, by domestic certification bodies. Indeed, domestic certification bodies are more appropriate and efficient than foreign certification bodies, as they do not have to face the problem of language barriers, they can adjust producer's visits to the production cycle, they cost less, and share the same culture with those they control. Domestic certification bodies can be locally accredited, which is the case of Vinacert, Mekongcert (Vietnam), ACT (Thailand), and the Lao Certification Body. Local certification bodies are evidence of a sense of ownership by local stakeholders. However, as accreditation is also a long, costly, and difficult process, in coun- 
tries where different standards may be under the responsibility of different ministries, it may be difficult to avoid the multiplication of accreditation and certification bodies, each ministry considering itself as fully legitimate. This is more likely to be the case as the number of voluntary standards increases (e.g. organic, safe, clean, VietGap, ThaiGap, ASEANGap).

(2) Control by a "Board" or "Committee": the Thai system, which offers the possibility for the GI association to choose its system of control (accredited certification body, Provincial Committee), allows the GI to be launched without charging the operators for certification costs from the very beginning. The problem of cost also justifies the choice made in Vietnam. Indeed, in most cases the producers/processors cannot afford such costs at the beginning of the activity, but are able to do so later on once the GI product is better remunerated on the market. These Control boards or Provincial committees bring together experts from DIP/NOIP, local authorities, experts on the product, and experts in control/certification. One possible disadvantage of this control system is that control is not always optimal or may even not work at all because of lack of skilled human resources to conduct inspection and possible difficulties in coordinating such multi-stakeholder boards.

(3) Control by participatory guarantee systems $(P G S s)^{27}$ are particularly appropriate for short value chains (local and domestic markets) as they enable producers to reduce certification costs and communities to engage in a learning process. They are also a very interesting instrument to raise consumer awareness about issues related to food quality. Indeed, PGSs allow greater communication and learning between farmers and consumers, as well as more information-sharing not only between the farmers themselves, but also with other segments of the value chain. PGSs are currently very popular in Vietnam.

In terms of overall strategy, there seems to be some rationale for the creation of "one-stop shops for certification". Bringing all agri-food certifications under the umbrella of a single certification body (national or regional) would make it possible for operators willing to access multiple certifications to benefit from economies of scale, provided that several certifications can be granted after a single inspection (e.g., organic, GAP, GIs, mandatory food safety regulations). This system would also enable inspectors from the certification body to attain a critical mass of activities to be fully operational, and not lose their skills. Such a system already exists for voluntary food standards, with certification bodies proposing certification packages that include a broad range of certifications (Djama, Fouilleux, and Vagneron 2011).

In parallel, and during the transition period until fully operational na-

27 Defined by IFOAM as "a quality assurance system for clusters based on an active participation of all the stakeholders and on the establishment of trust, social systems and knowledge exchanges between farmers, consumers and members involved" (IFOAM, 20xx). These alternative certification systems PGS are close to peer-to-peer systems. 
tional certification bodies are in place, it is important to encourage ongoing efforts toward regional cooperation in the area of certification. As multiple accreditations are costly and time-consuming, certification bodies tend to develop partnerships based on a strategy of specialization in either a geographic location or an accreditation. The Certification Alliance, a collaborative platform for regional certification, is an interesting example of such cooperation. Based on the premises that local certification may not be viable in countries where there are only a small number of operators, Certification Alliance offers an internationally accredited inspection and certification service to local operators as well as collaboration between members on information-sharing, learning and capacity-building in inspection and certification. On this platform, collaboration among different certification bodies allows each member to benefit from a menu of certifications. Local inspectors accompany experts from other member organizations during their inspections, and learn from the experience. In 2008, the Lao Certification Body joined this platform along with eight other Asian organic certification bodies.

Finally, while the European system designates a GI-competent authority to supervise the control scheme for GIs (INAO in France), such supervision of the control scheme by the GI national competent authority is questionable in the four countries concerned here. As they are currently learning the fundamental principles of internationally recognized certification procedures, it may be wiser not to further complicate matters by adding mandatory coordination of controls between the authorities in charge of accreditation and certification and those in charge of geographical indications (intellectual property department or office) to avoid extra costs of co-management.

\subsection{In the end, are GIs really equivalent to standards?}

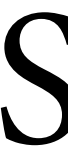
tandards imply a certain level of codification. In this respect, GIs are different from other standards: each GI specification is a unique standard, and inspectors need to truly understand the history and specific quality/uniqueness of the GI product. Furthermore, the uniqueness of the GI product may make it difficult to translate all its properties in the technical specifications without ending up with a very complicated document that is both unverifiable and unmanageable. For example, the experience of Kampot Pepper shows that having too many points to control (42 control points) is overly difficult and inefficient. The control points should be classified between major and minor points and the sensorial analysis should not be undermined: more importance should be given to the sensorial analysis and tasting panels as GIs give added value to typicity and organoleptic quality.

Another specificity of GIs is their collective nature. Each GI is a standard built on the practices of a group of producers/processors located in a specific place that created a product with a reputation. The group of producers/pro- 
cessors is thus essential not only when setting up the GI application, but also when implementing the internal control. Internal control was the main control in France before 2006, under the supervision of INAO. Internal control is critical as it paves the way for lighter, easier external control, enables farmers to share and learn from each other, and reduces the risk of non-compliance. External control can be facilitated by strong efficient internal control: for Kampot Pepper, only 16 farmers were subjected to external control.

\section{Conclusion}

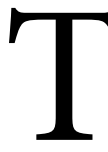

This article presents the GI control systems that are currently emerging in Southeast Asia, and highlights the difficulties encountered at various levels in making these systems both operational and credible, yet at a reasonable cost. While certification by internationally accredited third-party certification bodies is generally presented as the gold standard, it might not be the most suitable system for GIs, in terms of costs, sharing, and learning. Furthermore, a careful look at the latest version of the EU Regulation of 2012 shows that, for foreign GIs, third-party certification might not even be a precondition for entering EU markets. Finally, an increasing number of foreign GIs are protected in Europe through bilateral agreements that include a list of GIs to be protected in the signatory countries of the agreement, without having to rely on the provisions of the EU Regulation on GIs. In this sense, GIs are much more flexible than the
EU organic agriculture standard, which requires a 17065 certification system or a system judged to be equivalent to the European system. This means that countries willing to export GI products still have considerable latitude in the design of their certification schemes, and should consider several options in the light of the cost, the level of farmers' knowledge and awareness, and the domestic control capacities, with the aim of implementing efficient control.

\section{References}

Barham, E. and B. Sylvander. 2011. Labels of Origin for Food: Local Development, Global Recognition. CABI.

Belletti, G., T. Burgassi, A. Marescotti, and S. Scaramuzzi. 2007. "The Effects of Certification Costs on the Success of a PDO/PGI." In Quality Management in Food Chains, edited by Ludwig Theuvsen, Achim Spiller, Martina Peupert, and Gabriele Jahn, 107-121. Wageningen Academic Publishers.

Bowen, S. 2010. "Development from Within? The Potential for Geographical Indications in the Global South." The Journal of World Intellectual Property 13 (2): 231-252. doi:10.1111/j.17471796.2009.00361.x.

Bramley, C., D. Marie-Vivien, and E. Biénabe. 2013. "Considerations in Designing an Appropriate Legal Framework for GIs in Southern Countries." In Developing Geographical Indications in the South-The Southern African Expe- 
rience, edited by Cerkia Bramley, Estelle Biénabe, and Johann Kirsten, 15-50. Springer.

Crespi, J. M. and S. Marette. 2003. "Some Economic Implications of Public Labeling." Journal of Food Distribution Research 34 (3): 83-94.

Djama, M., E. Fouilleux, and I. Vagneron. 2011. In Governing Through Standards: Origins, Drivers and Limitations, edited by Stefano Ponte, Peter Gibbon, and Jakob Vestergaard, 184209. Londres: Palgrave Macmillan. (International Political Economy Series).

Evans, G. E., and Michael Blakeney. 2006. "The Protection of Geographical Indications After Doha: Quo Vadis?" Journal of International Economic Law 9 (3): 575-614. doi:10.1093/jiel/jgl016.

François, M. and Seyrevath Prak. 2006. Indications Géographiques au Cambodge Phnom Penh, GRET-CEDAC, Cambodian Institute for Research and Rural Development.

Gibbon, P. and O. Memedovic. 2006. Decoding Organic Standard-setting and Regulation in Europe(1991-2005), UNIDO Working Paper, Vienna, 56 p.

Guthman, J. 2007. "The Polanyian Way? Voluntary Food Labels as Neoliberal Governance." Antipode 39 (3): 456-478.

Hatanaka, M., C. Bain, and L. Busch. 2005. "Third-Party Certification in the Global Agrifood System." Food Policy 30: 354-369.
Hughes, J. 2009. Coffee and Chocolate: Can We Help Developing Country Farmers Through Geographical Indications?: A report for the International Intellectual Property Institute, Washington, D.C.

Jahn, G., M. Schramm, and A. Spiller. 2005. "The Reliability of Certification: Quality Labels as a Consumer Policy Tool." Journal of Consumer Policy 28: 53-73.

Marie-Vivien, D., L. Bérard, J-P. Boutonnet, and F. Casabianca. 2015. "Are French Geographical Indications Losing Their Soul? Analyzing Recent Developments in the Governance of the Link to the Origin in France." World Development no. XX.

Marie-Vivien, D., L. Bérard, J.-P. Boutonnet, \& F. Casabianca. 2017. "Are French Geographical Indications Losing Their Soul? Analyzing Recent Developments in the Governance of the Link to the Origin in France." World Development 98(October): 25-34.

Marie-Vivien, D., and D. Chabrol. 2014. "Geographical Indications (GIs), Biodiversity and Poor Communities": The Opportunity of GIs to Provide Protection of Traditional Indigenous Biodiversity Products and Benefits to Poor Agricultural Communities: A Desk Study on Six Target Countries: Cambodia, Laos, Indonesia, Vietnam, Ethiopia, Mauritania. Unctad-Crops for the Future-Cirad.

Marie-Vivien, D., C.A. Garcia, C. G. Kushalappa, and P. Vaast. 2014. "Trade- 
marks, Geographical Indications and Environmental Labelling to Promote Biodiversity: The Case of Agroforestry Coffee in India." Development Policy Review 32 (4): 379-398. doi:10.1111/ dpr.12060.

Ngokkuen, C. and U. Grote. 2013. "Challenges and Opportunities for Protecting Geographical Indications in Thailand." Asia-Pacific Development Journal 19 (2, December): 93-123.

Olszak, N. 2007. "Actualité du droit des signes d'origine et de qualité (indications géographiques, labels)." Propriété industrielle 9: 6-10.

Pick, B., D. Marie-Vivien, and D. Bui_ Kim. 2015. "Geographical Indications in Vietnam: A Promising Tool for Socio-Economic Development?" In Geographical Indication at the Crossroads of Trade, Development and Culture in Asia-Pacific. Singapore: Faculty of Law, National University of Singapore.
Rangnekar, D. 2004. "The Socio-Economics of Geographical Indications. A Review of Empirical Evidence from Europe." UNCTAD/ICTSD Capacity Building Project on Intellectual Property Rights and Sustainable Development no. 52 .

Sylvander, B. 1997. "Le rôle de la certification dans les changements de régime de coordination : l'agriculture biologique, du réseau à l'industrie." Revue d'économie industrielle 80 (1): 47-66.

Sylvander, B., F. Casabianca, and F. Roncin. 2008. Colloque International "Produits agricoles et alimentaires d'origine: enjeux et acquis scientifiques". Paris: INRA Editions. 